\title{
Authentic Classroom Leaders: The Student Perspective
}

\author{
Megan S. Downing \\ University of Northern Kentucky \\ Highland Heights, Kentucky
}

\begin{abstract}
In a qualitative study assessing students' perceptions of faculty-student interaction in the online learning environment, findings demonstrated that students make meaning of facultystudent interaction in ways that align with authentic leadership behaviors. Faculty interaction, or lack thereof, shaped students' perceptions of faculty authenticity and commitment to students' learning outcomes. Students indicated satisfaction in their leadership learning experience when instructors were perceived as authentic in their actions.
\end{abstract}

\section{Authentic Classroom Leaders: The Student Perspective}

Understanding student perceptions of faculty-student interaction as authentic classroom leaders can help educators make informed choices when teaching and interacting with students. Social presence and demonstrated instructor immediacy influence learner satisfaction in both the traditional (Christophel, 1990) and online learning environments (Richardson \& Swan, 2003). When instructor presence is lacking, the student experience is negatively impacted and revealed in decreased motivation, satisfaction, and perceived levels of learning (Richardson \& Swan, 2003). Faculty actions or inaction inform students' perceptions of faulty commitment and authenticity and, ultimately, students' perceived learning experience.

Assessing Social Presence and Faculty Interaction in the Online Environment. To assess student perceptions of social presence and faculty-student interaction in the online learning environment (OLE), qualitative data were collected through survey and interviews from actively enrolled online students in an undergraduate leadership program ([redacted], 2012). Of the 219 students invited to participate, forty five students responded to the survey and eight students volunteered to participate in confidential interviews. Descriptive survey and interview results were analyzed through a social presence framework (Short, Williams, \& Christie, 1976), holistically reviewed, and openly coded using a constant comparative method. Data were then reviewed to reveal student identified instructor practices and social presence indicators using a modified template for assessing social presence based on the early work of Rourke, Anderson, and Garrison (1999). The importance of certain instructor practices was determined based on the relative presence of 15 indicators of social presence in one of four categories: (a) Affective, (b) Interactive, (c) Cohesive, and (d) Functional in student responses. All indicators were present within the results, with instructor actions aligning with the following eight indicators showing greatest prevalence: feedback, demonstrated caring, instructor availability, timely communication, course design, personal contact, administrative communication, and validation behaviors (complimenting, expressing appreciation, providing confirmation) ([redacted], 2012). Data were then reviewed to identify recurring themes that revealed the meaning students ascribe to these practices. The following thematic units emerged as factors that resonated among 
students' perceptions of faculty interaction (a) authenticity; (b) validation; and (c) reinforcement ([redacted], 2012).

Student Perceptions of Faculty-Student Interaction. Findings demonstrated that students make meaning of faculty-student interaction in ways that align with leadership behaviors, in particular, authentic leadership. Students were sensitive to instructor actions that demonstrated commitment, caring, and sincerity. Instructors whose actions did not model these behaviors were described as "going through the motions" and were not viewed as authentic instructors. Feedback was the most prevalent indicator, followed by instructor availability, demonstrated caring, course design, personal communication, and complimentary communication ([redacted], 2012).

Authentic Behaviors. Authentic behaviors such as caring, demonstrated commitment, and sincerity, are factors that establish connections and foster trust (Manning \& Curtis, 2011). When trust and respect are present, the classroom environment fosters relationship building and an open exchange of ideas. For an instructor to be perceived as authentic, their "motives, actions, intentions, values, and purpose" (Lynn, 2008, p. 135) must be in alignment. As one student noted, "I think too, with the professors, I mean, they've chosen this area [leadership], as their area of expertise. So, I find them all to be perfecto." Another emphasized, "I think what's equally important is that the professors, those who are really connected, you can tell that...it's in their DNA. They care, they truly have a passion to teach and transfer the knowledge and their skill base to others" ([redacted], 2012).

Validating Behaviors. Validating behaviors foster a sense of connection, satisfaction, recognize achievements, and cultivate students' sense of self-respect. These concepts manifested in several student responses that exhibited perceptions of belonging, of being appreciated, valued, and respected. One survey respondent shared this validating experience: "The instructor quickly responded to my questions on a project and was quite encouraging. I was treated as an adult and as if she was mentoring me; guiding me on my path of learning" ([redacted], 2012).

Reinforcing Behaviors. Reinforcing behaviors were pervasive across the data and crossed boundaries with validation and authenticity. Feedback was the most prevalent reinforcing behavior, along with friendly course announcements and emails that provide reassurance and guidance, clarifying assignment expectations as needed. Some students recognized the "immediate gratification" that faculty communication can provide, while others emphasized the "motivation" a simple email can provide. Conversely, when reinforcing behaviors were not present, students explained that they experienced anxiousness, doubt, and confusion. As one survey respondent noted, "I am not sure how I got on the right track nor do I understand how to get back on the right track [when I need to]" ([redacted], 2012).

Roadmap to Authentic Leadership Instruction. Theoretical research demonstrates that authentic leadership focuses on leaders' developmental capacities (Northouse, 2013) toward selfawareness, moral perspective, balanced processing, and relational transparency (Walumba, Avolio, Gardner, Wernsing, \& Peterson, 2008). Practical application of these personal developmental concepts is relevant for instructors who seek to build trusting relationships with their students. Instructors who follow a roadmap for authentic leadership by fostering student 
perceptions of authenticity, validation, and reinforcement can develop the capacity for authentic classroom leadership. Instructors whose social presence behaviors exhibited these characteristics were highly praised by students and were described as "passionate," "committed," "caring," and "dedicated" in their faculty-student experiences. Based on the stories shared by their students, these instructors have mastered the ability to foster an environment of trust, central to authentic leadership behaviors. Instructors whose actions did not model these behaviors were not viewed as authentic instructors. Although this study explored student perceptions of faculty behaviors in the online environment, the findings are transferable to other educational settings and provide the initial evidence that demonstrates the deep-seated impact authentic instructors have on students' educational experience.

\section{References}

Christophel, D. M. (1990). The relationships among teacher immediacy behaviors, student motivation and learning. Communication Education 39(4), 323-340.

Downing, M. S. (2012). Student perceptions of instructor-student interaction in online learning (Doctoral dissertation). Retrieved from ProQuest (3512815)

Lynn, A. B. (2008). The EQ interview: Finding employees with High Emotional Intelligence. New York, NY: AMACOM.

Manning, G. \& Curtis, K. (2011). The art of leadership. New York, NY: McGraw-Hill.

Northouse, P. G. (2013). Leadership: Theory and practice (6th ed.). Thousand Oaks, CA: Sage Publications, Inc.

Richardson, J. C., \& Swan, K. (2003). Examining social presence in online courses in relation to students' perceived learning and satisfaction. Journal of Asynchronous Learning Networks, 7(1), 68-88.

Rourke, L., Anderson, T. Garrison, D. R., \& Archer, W. (1999). Assessing social presence in asynchronous text-based computer conferencing. Journal of Distance Education, 14(2), 50-71. Retrieved from http://cade.athabascau.ca/vol14.2/rourke_et_al.html.

Short, J., Williams, E., \& Christie, B. (1976). The social psychology of telecommunications. London, United Kingdom: John Wiley \& Sons.

Walumba, F. O., Avolio, B. J., Gardner, W. L., Wernsing, T. S. \& Peterson, S. J. (2008). Authentic leadership: Development and validation of a theory-based measure. Journal of Management, 34(1), 89-12. 